\title{
EFFECTIVENESS OF USING THE SYNTACTIC TREE STRUCTURE APPROACH IN TEACHING VOCABULARY TO LOW PROFICIENCY ESL LEARNERS
}

\author{
SHARON SUI-LIN LIM*, NIK IZYANI NIK NORDIN AND ROSYATI ABDUL RASHID
}

${ }^{I}$ English Language Learning Centre, Centre for Fundamental and Continuing Education, Universiti Malaysia Terengganu.

*Corresponding author: sharon@umt.edu.my

Submitted final draft: 7 July $2020 \quad$ Accepted: 28 August $2020 \quad$ http://doi.org/10.46754/jbsd.2020.09.004

\begin{abstract}
Low proficiency ESL learners often encounter a lot of learning problems, particularly due to their lack of vocabulary, which is evident in their incorrect usage of words. This study was an attempt to aid 85 low proficiency ESL learners to easily comprehend the forms and functions of 80 target words, selected from the 2000 level General Word List, using the syntactic tree structure approach. Prior to the intervention, a vocabulary test based on 80 words, which were later introduced to the students in their course book, was administered to the students. The same test was given again to the students upon the completion of the third lesson. To determine the possible significant influence of the intervention, the pre-test and post-test data were analysed using the paired-samples t-test. The analysis yielded a significant result $(t(84)=7.31, \mathrm{p}<.05$ (two-tailed)). When the students' mean test scores of the two tests were compared, a statistically significant increase of 7.5 points was observed, implying the success of the intervention. The calculated effect size was also large $(\mathrm{y}=.39)$. However, since no control group was introduced in the study, caution should be taken in making any strong claims on a causal relationship.
\end{abstract}

Keywords: Syntactic tree structure approach, low proficiency, vocabulary

\section{Introduction}

Tertiary ESL learners are encouraged to master a wide range of vocabulary for better communication outside of the academic world within a more civilised society. This is due to the fact that vocabulary is the essential base and key to comprehension (Sulaiman \& Salehuddin, 2018). Besides, ESL learners are also expected to cope with academic texts whereby the majority of those texts are written in the English language. Many researchers have contended that undergraduates need to have a repertoire of 3,000 word families to understand authentic texts at university, and 10,000 word families to read and comprehend academic textbooks successfully (Laufer, 1992; Hazenberg \& Hulstijn, 1996). However, the many research in Malaysia indicates that many, if not most, Malaysian undergraduates are not even close those figures (Kaur, 2013; Lim, 2014; Harji et al., 2015; Ibrahim et al., 2016; Mokhtar \& Mohd Rawian, 2016; Lateh et al., 2018; Zuriyani \& Mohamed Ismail, 2019). Some lower proficiency learners do not even have a repertoire of 2000 most frequently used words. They need to master these words first as they cover $87 \%$ of running words in texts (Nation, 1990). It is said that lower proficiency learners can close the vocabulary gap of their more proficient peers by adding 1000-2000 words per year to their repertoire (Nation, 1990), but that seems to be an insurmountable task. How, then can these learners speed up the process of acquiring new words and 
also use them correctly? The researchers believe that by learning vocabulary using the syntactic tree structure approach, it will help the low proficiency learners to utilise words correctly. Although the syntactic tree structure approach has been utilised as a tool to teach grammar (Huang, 2019), the usage of the syntactic tree structure approach can also be extended to teaching vocabulary.

In order to build students' vocabulary, it is necessary to understand what constitutes "knowing" a word. Nation (1990) suggests that the following nine types of knowledge are needed to know a word:

1. Knowledge of the spoken form of a word

2. Knowledge of the written form of a word

3. Knowledge of the parts of a word which have meaning

4. Knowledge of the link between a particular form and a meaning

5. Knowledge of the concepts a word may possess and the items it can refer to

6. Knowledge of the vocabulary that is associated with a word

7. Knowledge of a word's grammatical form

8. Knowledge of a word's collocations

9. Knowledge of a word's register and frequency

When students have greater syntactic awareness, they can form meaning mapping and can also identify grammatical functions of a word in a text (Nagy \& Scott, 2000). Once students can analyse the structure of a sentence, it assists in building multiple meanings that come from a single form (Park \& Warschauer, 2016). For example, the word "seal", which refers to an animal species, can also mean to secure things, and a piece of wax attached to a document.
Becker (1975) first proposed the concept of lexical chunks, whereby lexical chunks were seen as phrasal lexicons, in a fixed or semi-fixed pattern between traditional grammar and vocabulary (Huang, 2019). However, Lewis (1993) regarded it as a multi-word unit made up of two or more inseparable words with semantic and syntactic meaning. Huang (2019) further elaborated that Lewis (1997) classified lexical chunks into four categories corresponding to the syntactic function and semantic relationship between words. Similarly, the writers have adopted Lewis' classification and consider an English sentence as composed of several phrases of many types, i.e. noun phrase, verb phrase, adjective phrase, adverbial phrase, and prepositional phrase.

In a study by Enesi (2017), 30 students answered two exercises on word formation from a third-year course book. No theory about word formation processes were included in the book. The results showed that $55 \%$ of the students answered 1-5 questions correctly, while $45 \%$ answered correctly 5-10 questions. This result shows the need for the inclusion of word formation theory in teaching the English language, especially attempts to enhance new vocabulary knowledge.

Thus, the present study focuses on word formation, especially on the usage of suffixes, as it changes the grammatical category of a word. The syntactic tree approach was used as it would help students visualise the position of word category and how it fits into a sentence.

\section{Methodology}

\section{Participants}

The 85 participants of this action research study were first-semester students who obtained Band 1 or Band 2 for the MUET exam ( $\mathrm{N}=19$ male, $\mathrm{N}=66$ female). 58 of the 
participants were enrolled in a Humanities programme, while 27 participants were enrolled in 6 different Science programmes. All of them were registered for the English proficiency classes taught by the researchers.

\section{Background and context of Study}

The researchers were involved in teaching several groups of an English proficiency course at a local public university. The English proficiency course is mandated for students who had obtained Band 1 or Band 2 in their Malaysian University Entrance Exam (MUET). One of the effects of low proficiency is that the learners are hampered by a small vocabulary size. This study was an attempt to aid low proficiency ESL learners to easily comprehend the forms and functions of selected target words from the 2000-word level General Word List, using the syntactic tree structure approach.

In order to achieve this, three lessons were designed to be taught over a period of three weeks. Prior to the lessons, the learners were asked to answer a word forms and functions test on the form and functions of 80 target words. The target words were taken from the vocabulary builder that the learners used in their course. These words are from the 2000-word level General Word List. The 80 target words were randomly selected from the vocabulary builder. The first lesson was to introduce the concept of the syntax tree to the learners. After a short lecture, the learners were given guided exercises and also several activities. At the end of the first lesson, they were asked to complete an enrichment activity on their own before the next class.

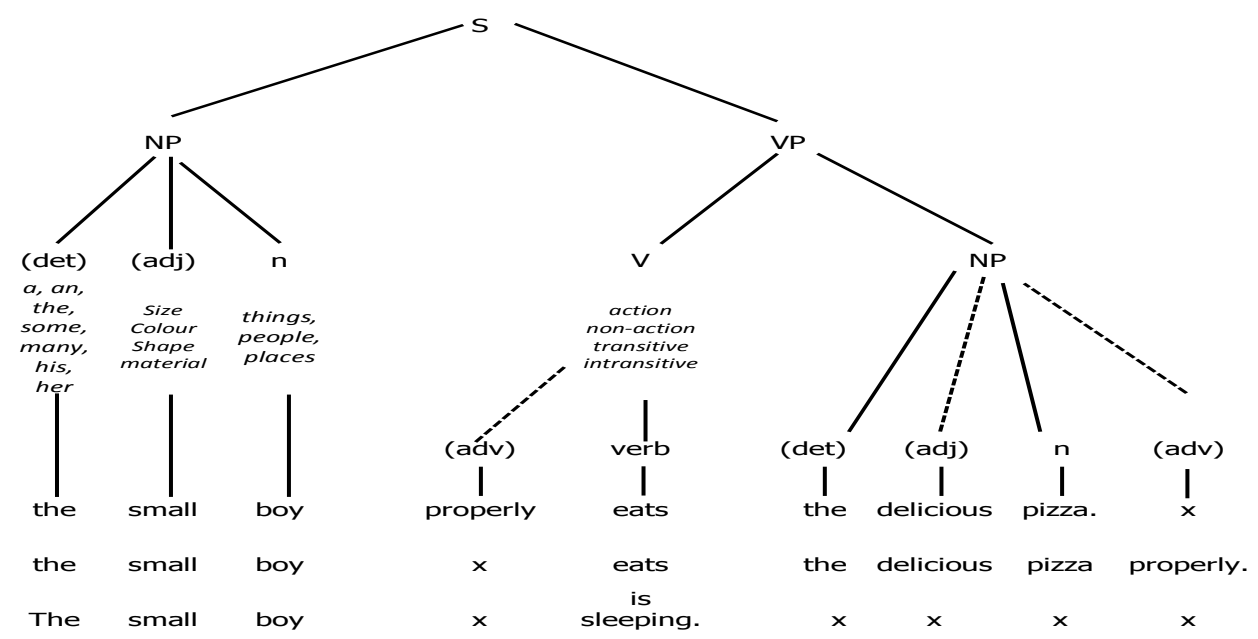

Figure 1: Example of basic sentence structure in Lesson 1

The second and third lessons concentrated on adjectives and adverbs, respectively, in relation with the syntax tree. These lessons began with a refresher of the previous lesson. The refresher was conducted in the form of games. Following that, the lesson then turned to the focus, which was adjectives and adverbs, during the second and third lessons, respectively.
Each lesson began with guided exercises before students were given activities to reinforce the lessons on adjectives or adverbs and also the syntax tree, followed by enrichment exercise or activity. For each lesson, the learners were given notes so that they could follow the lesson. After the lesson on adverbs was completed, the learners were asked to answer the word 
forms and functions test, which tested the forms and functions of the 80 selected target words.

\section{Aim of the study}

The aim of the study was to ascertain whether ESL learners' performance in comprehending the forms and functions of words would be enhanced by learning the syntactic tree structure approach. The study sought to answer the following research questions:

RQ1: Is there a significant difference between the pre- and post-test mean scores?

RQ2: What is the effect size for the difference in mean scores for the word forms and functions test?

RQ3: How many percent of the students showed improvement in their word forms and functions test performance?

\section{Instruments}

The quantitative data were collected using a word forms and functions test comprising of 80 items. 40 items were made up of 40 multiple-choice questions that tested the students on their knowledge on the form of the target words, and another 40 multiplechoice questions that focused on the function of the target words. The pre-test and post-test were carried out online.

The withness answered the questions with a voice.

$\begin{array}{llll}\text { A. firmness } & \text { B. firmed } & \text { C. firm } & \text { D. firmly }\end{array}$

Figure 2: Example of question on word form
Instruction: Identify the category of the
underlined word.
Parents should treat their kids fairly.
$\begin{array}{llll}\text { A. Noun } & \text { B. Verb } \quad \text { C. Adjective } \quad \text { D. Adverb }\end{array}$

Figure 3: Example of question on word function

\section{Data Analysis}

This action research study obtained data from the pre- and post-test, which were then analysed using SPSS ver.25. Only the results from participants who sat for both the pre- and post-tests were analysed.

\section{Results and discussion}

To answer Research Question 1, the pairedsamples t-test was conducted on the data collected from both 80 -item vocabulary pretest and post-test administered to $85 \mathrm{ESL}$ learners before and after the intervention or instruction based on the syntactic tree approach. As shown in Table 1, the statistical analysis produced a significant result $(\mathrm{t}(84)=7.31, \mathrm{p}<.05)$, implying the success of the intervention. The learners' post-test mean score was higher than that of the pre-test score. When the two mean scores were compared, there was an increment of 7.5 points, indicating quite a marked improvement in the vocabulary test score. However, the computed mean scores were not high; the mean for the pretest was 39.53 and for the post-test 44.07. Both mean scores reflected that the learners failed the test prior to the intervention and only managed to pass it after receiving the short instruction based on the syntactic tree approach. Such results were not surprising since the learners were weak in their English proficiency as they had 
had scored only Band 1 or Band 2 in their MUET examination prior to their admission to university. Moreover, the learners were taught and guided to use the syntactic tree approach for only a very short period of time (i.e., a three-week instruction).

Table 1: Analysis of pre and post test on word forms and functions test

\begin{tabular}{cccccc}
\hline & \multicolumn{2}{c}{ Pre-test } & \multicolumn{2}{c}{ Post-test } & $\begin{array}{c}\text { Mean } \\
\text { Difference }\end{array}$ \\
\hline Forms and Functions & $\mathrm{M}$ & $\mathrm{SD}$ & $\mathrm{M}$ & $\mathrm{SD}$ & \\
\cline { 2 - 6 } & 36.53 & 9.54 & 44.07 & 10.72 & 7.5 \\
\hline
\end{tabular}

The effect size for the difference in mean scores between the pre-test and posttest was calculated to answer Research Question 2. Cohen (as cited in [12]) proposes three categories of effect size values: small $(\mathrm{y} \geq .01)$, moderate $(\mathrm{y} \geq .06)$, and large $(\mathrm{y} \geq .14)$. The computed value for the effect size in this study was $\mathrm{y}=.39$, a value which fits Cohen's large effect size value. This large effect size value shows that the difference in the vocabulary mean test score between the pre-test score and post-test score is big, and this value is of practical importance and should, therefore, not be ignored. In other words, ESL instructors should consider adopting the syntactic tree approach in teaching vocabulary since the present study produced evidence that indicated that learners who had undergone an instruction based on this approach successfully showed a significant improvement in their vocabulary test score.

Close inspection of the descriptive data of the present study was done to answer Research Question 3. The analysis yielded a positive result. When comparisons were made of learners' pre-test and post-test scores, $81 \%$ of the learners involved in the study were found to have had a positive test score increment. This improvement is very encouraging as this was a result of only a three-week instruction.

\section{Conclusion}

The present study was carried out to test the effectiveness of using the syntactic tree structure approach to aid lower proficiency ESL learners to learn vocabulary and to use the words correctly. To be a member that contributes in any Madani (modern) society, the lack of vocabulary issue must be addressed seriously, otherwise, it will hinder his or her ability to function competently in society. As evident from the present study, the results have shown that learners are able to grasp the concept, although it was only taught within a three-week period, as evidence by the post-test scores. However, the study has also its limitation, especially since no control group was introduced in the study, hence, caution should be taken in making any strong claims on a causal relationship. Future research should include a control group, and the lessons should be further developed, especially in word forms, in order to have a bigger impact on learners' vocabulary learning.

\section{Acknowledgements}

Authors wish to thank the university for the research opportunity and the reviewers and editors for the comments on this manuscript.

\section{References}

Enesi, M. (2017). The effect of teaching word formation theory to English students. European Journal of Language and Literature Studies, 3(1), 7-12. https://dx.doi.org/10.26417/ejls. v7i1.p7-12 
Harji, M.B., Balakrishnan, K, Bhar, S.K., \& Letchumanan, K. (2015). Vocabulary levels and size of Malaysian undergraduates. English Language Teaching, 8(9), 119-130. DOI:10.5539/ elt.v8n9p119

Hazenberg, S. \& Hulstijn, J. H. (1996). Defining a minimal receptive second language vocabulary for non-native university students: An empirical investigation. Applied Linguistics 17(2), 145-163.

Huang, D. (2019). The potential of sentence trees in English grammar teaching. English Language Teaching, 12(3), 178-190.

Ibrahim, E. H. E., Sarudin, I. \& Muhamad, A. J. (2016). The relationship between vocabulary size and reading comprehension of ESL learners. English Language Teaching, 9(2), 116123.

Kaur, N. (2013). A case study of tertiary learners' capability in lexical knowledge. GEMA Online Journal of Language Studies, 13(1), 113-126.

Lateh, N. H. M., Shamsudin, S., \& Abdul Raof, A. H. (2018). Receptive vocabulary levels of Malaysian university students. LSP International Journal, 5(1), 105-113.

Laufer, B. (1992). How much lexis is necessary for reading comprehension? In Arnaud, P.J.L., Bejoint, H. (eds). Vocabulary and Applied Linguistics. Lim, S. S. (2014). English vocabulary level and inferencing skills of new varsity learners. International Seminar on Language Teaching (ISoLT). Universiti Malaysia Kelantan. Nagy, W., \& Scott, J. (2000). Vocabulary processes. In M.Kamil, P. Mosenthal, P.Pearson, \& R. Barr (Eds.). Handbook of Reading Research, 3, 269-284Nation, I. S. P. (1990). Teaching \& Learning Vocabulary. Boston, Massachusetts. Heinle \& Heinle Publishers.

Mohktar, A. A., \& Mohd Rawian, R. (2016). English lexical acquisition of adult learners in instructional settings: Issue on lexical input. Proceedings of International Seminar on Generating Knowledge Through Research (ICECRS), 1(2016), 381-390. Article DOI: $\quad$ http://dx.doi.org/10.21070/ picecrs.v1i1.506.

Sulaiman, N. A. \& Salehuddin, Z. (2018). Academic word list knowledge of Malaysian ESL undergraduates. GEMA Online Journal of Language Studies, 18(4), 1-14. http://doi.org/10.17576/ gema-2018-1804-01

Zhang, D. (2012). Vocabulary and grammar knowledge in second language reading comprehension: A structural equation modelling study. The Modern Language Journal, 94(2). 558-575. https://doi. org/10.1111/j.1540-4781.2012.01398.x

Zuriyani, M. Y. \& Mohamed Ismail, A. S. (2019). The interactive roles of lexical knowledge and reading strategies on reading comprehension performance. Journal of Nusantara Studies, 4(1), 273-299. http://dx.doi.org/10.24200/ jonus.vol4iss1pp273-299. 